\title{
Chronic Subdural Hematoma after Endoscopic Third Ventriculostomy: A Case Report and Literature Review
}

\author{
Endoskopik Üçüncü Ventrikülostomi Sonrası Kronik Subdural Hematoma: \\ Olgu Suпити ve Literatürün Gözden Geçirilmesi
}

\author{
Tamer TEKIN ${ }^{1}$, Ahmet COLAK ${ }^{2}$, Murat KUTLAY ${ }^{2}$, Mehmet Nusret DEMIRCAN $^{2}$ \\ ${ }^{1}$ Van Military Hospital, Department of Neurosurgery, Van, Turkey \\ ${ }^{2}$ GATA Haydarpasa Training Hospital, Department of Neurosurgery, Istanbul, Turkey
}

Presented in: 2nd Hydrocephalus Symposium 2007, Cesme, Izmir, Turkey.

Correspondence address: TamerTEKIN / E-mail: tamer.tekin@yahoo.com.tr

\begin{abstract}
Chronic subdural hematoma is a very rarely observed complication after endoscopic third ventriculostomy (ETV). A 21-year-old male patient was admitted to our clinic with complaining of headache, weakness and tremor. The fundoscopic examination revealed slightly indistinct border of the papilla and neurological examination findings were normal. The cranial computed tomographic (CT) and magnetic resonance imaging (MRI) findings demonstrated three-ventricular hydrocephalus due to aqueductal stenosis and ETV was performed. The symptoms got better after the operation. At $1 \frac{1}{2}$ month postoperatively the patient reapplied to our clinic with a symptom of severe headache. Cranial BT imaging demonstrated enlargement of subdural hematoma. The hematoma was treated by burr-hole evacuation and drainage and totally disappeared in the postoperative period. The follow-up CT scan was evaluated as normal. Nowadays, ETV is accepted as a safe and an alternative method for the treatment of obstructive hydrocephalus instead of shunt operation. Chronic subdural hematoma is a rarely observed complication after ETV.
\end{abstract}

KEYWORDS: Complication, Endoscopic third ventriculostomy, Subdural hematoma

öz

Kronik subdural hematom endoskopik üçüncü ventrikülostomi (ETV) sonrası nadiren görülen bir komplikasyondur. 21 yaşında erkek hasta baş ağrısı, halsizlik ve tremor yakınmaları ile kliniğimize başvurdu. Fundoskopik muayenesinde papil sınırları hafif silik ve nörolojik muayenesi doğaldı. Kranial bilgisayarlı tomografi ve manyetik rezonans görüntülemede akuadukt stenozuna bağlı triventriküler hidrosefali bulguları görüldü. Sonra ETV uygulandı. Operasyon sonrası semptomlar düzeldi. Operasyondan $1 \frac{1}{2}$ ay sonra hasta ciddi başağrısı semptomuyla kliniğimize tekrar müracaat etti. Kranial BT görüntülemede subdural hematom geliştiği görüldü. Hematom, burr hole ile boşaltılıp, drene edildi. Postoperatif dönemde tamamen kayboldu. Kontrol BT taraması normal olarak değerlendirildi. Günümüzde, ETV obstrüktif hidrosefalinin tedavisinde şant operasyonlarına alternatif ve güvenli bir yöntem olarak kabul edilmektedir. Kronik subdural hematom ETV sonrası nadir olarak görülen bir komplikasyondur.

ANAHTAR SÖZCÜKLER: Komplikasyon, Endoskopik üçüncü ventrikülostomi, Subdural hematom

\section{INTRODUCTION}

The use of endoscopic techniques for the treatment of hydrocephalus has been managed since the beginning of the $20^{\text {th }}$ century. The replacement of rigid instruments with flexible equipments, a decrease in the size of the instruments and advances in fiberoptic technology have lead to a great deal of change to the present time $(3,5,8,9,11,15)$. This conversion fostered neurosurgeons, who frequently encounter complications associated with infection due to shunt, bleeding and foreign-body reactions in the treatment of hydrocephalus, to prefer neuroendoscopic techniques more commonly $(10,11,13)$. Endoscopic third ventriculostomy (ETV) has become a popular treatment approach especially for obstructive hydrocephalus although it can be used for a variety of methods such as colloid cyst resection and fenestration of arachnoid cysts $(4,7,11,13,14)$. Even though it is a new technique, the calculated complication rates of ETV technique were found to be smaller than those of the shunt technique, which made it a more reliable and appropriate process $(4,10,13)$. The more widespread use of ETV in the neurosurgery clinics, has increased the experiences of the neurosurgeons in this area; however, more detailed studies on the complications are needed.

A small number of adult patients with chronic subdural hematoma after ETV have been reported in the literature (Table I). We present a 21-year-old male subject who 
Tablo I: Adults Subdural Collection Cases Reported in the Literature

\begin{tabular}{|l|l|l|l|l|}
\hline Author & Age and sex & Cause of hydrocephalus & Localization & Subdural collection \\
\hline Beni Adani L et al. 1994 & $20 y$, male & obstructive hydrocephalus & ipsilateral & chronic SDH \\
\hline Beni Adani L et al. 2000 & $20 y$, male & obstructive hydrocephalus & ipsilateral & chronic SDH \\
Shroeder HWS et al. 2002 & $\begin{array}{l}25 \mathrm{~d} \text {, male } \\
66 y \text {, male }\end{array}$ & $\begin{array}{l}\text { obstructive hydrocephalus } \\
\text { unknown }\end{array}$ & $\begin{array}{l}\text { bilateral } \\
\text { ipsilateral }\end{array}$ & $\begin{array}{l}\text { subdural collection } \\
\text { subdural collection }\end{array}$ \\
\hline Sgaramella E et al. 2003 & $69 y$, male & obstructive hydrocephalus & contralateral & chronic SDH \\
Kim BS et al. 2003 & $51 y$, male & obstructive hydrocephalus & bilateral & chronic SDH \\
Kamel MH et al. 2006 & $16 y$, female & obstructive hydrocephalus & ipsilateral & chronic SDH \\
Civelek E. et al 2007 & $42 y$, female & obstructive hydrocephalus & contralateral & chronic SDH
\end{tabular}

SDH: Subdural hematoma

developed chronic subdural hematoma (CSDH) after ETV. We discuss the possible physiopathology of the occurrence and management of this complication with a review of the literature.

\section{CASE REPORT}

A 21-year old male patient was admitted to our clinic with complaints of headache, asthenia, memory loss, tremor, and recurrent urinary incontinence persisting for ten years. He had ahistory of meningitis at the age of three. His complaint of headache increased gradually. The borders of the papillae were unclear on the fundoscopic examination. His neurological examination was normal.

Ventricular widening and obstructive hydrocephalus due to aqueductal stenosis was diagnosed on the cranial CT and MR imaging. No findings of mass lesion were determined (Figure 1, 2). We performed ETV. A burr hole was placed in the midpupillary even right frontal line, $1 \mathrm{~cm}$ anterior to the coronal suture during the operation. The patient was continuously irrigated with $10-20 \mathrm{ml} / \mathrm{min}$ of Ringer's lactate at body temperature during the procedure. The ventricle was traversed by $14 \mathrm{~F}$ catheter with a stopper. The base of the third ventricle was first cauterized and then perforated just posterior to the infundibular recess and tuber sinerium after endoscopic images were obtained. The fenestration was widened using a 3F Fogarty balloon catheter. The endoscopic examination revealed the constant correlation between the pre-mesencephalic cisternal space and the pre-mesencephalic subarachnoid space. No bleeding was observed. The burrhole was covered with a piece of spongostan following the application. Postoperatively the patient had no complaints and was discharged from hospital. The patient was readmitted to our department with severe headache $1 \frac{1}{2}$ months after the operation. Cranial CT scan revealed a right fronto-parietal chronic SDH (Figure 3). The patient underwent burr-hole drainage for hematoma. The symptoms disappeared during the postoperative period. Follow-up CT scan showed no indications of subdural collection (Figure 4).

\section{DISCUSSION}

ETV is a more suitable technique than shunt surgery for neurosurgeons since ETV decreases the incidence of

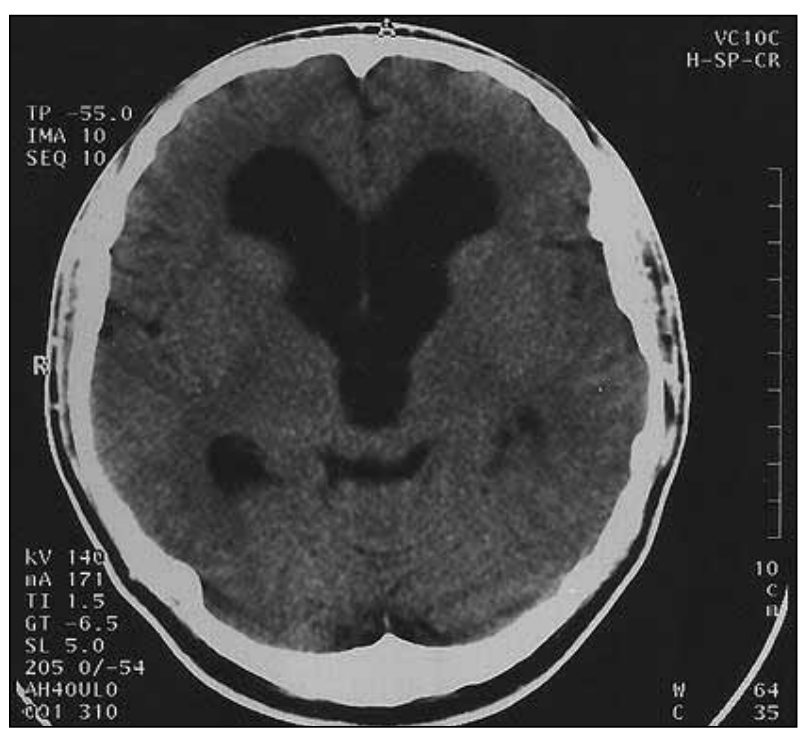

Figure 1: CT scan that demonstrates obstructive hydrocephalus and dilation of lateral ventricles and third ventricles.

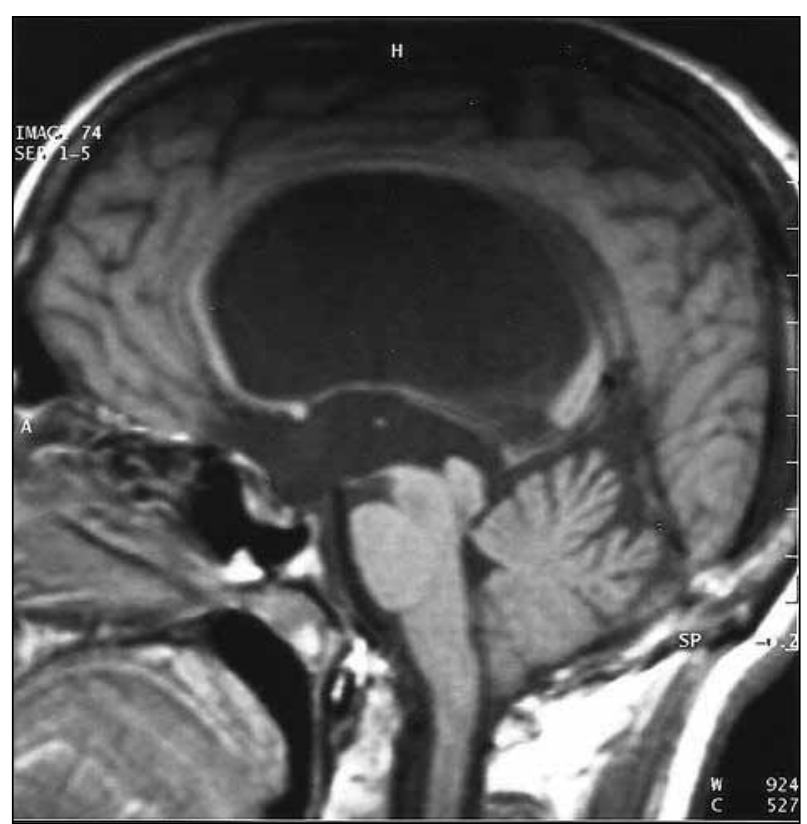

Figure 2: Sagittal T1 MRI showing the distal aqueductal stenosis. 


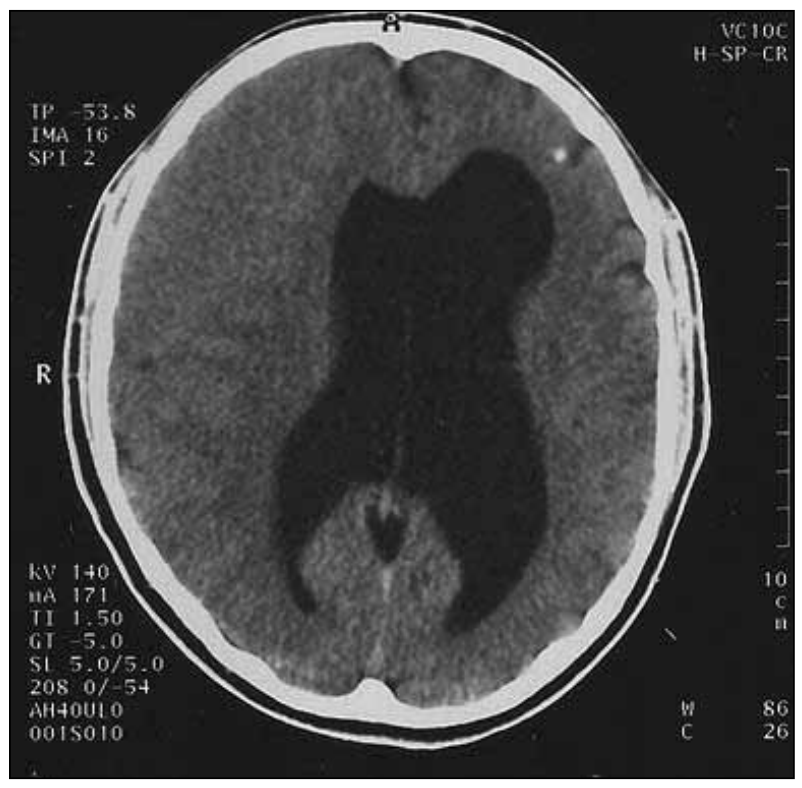

Figure 3: Postoperative CT scan that demonstrates right frontoparietal chronic SDH after the endoscopic third ventriculostomy.

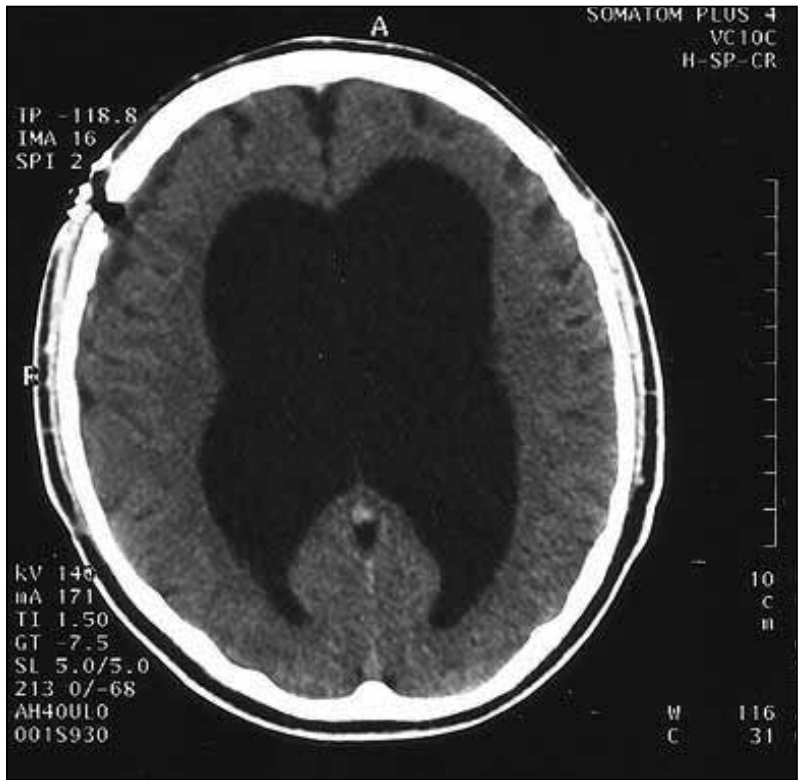

Figure 4: Postoperative CT performed after ETV showed the drained and smaller ventricles with no subdural collection.

problems such as infection, foreign-body reaction and lowpressure symptoms and shortens the duration of surgery $(5,8)$. ETV interventions result in a high degree of success as well as a low complication rate, especially in subjects with obstructive hydrocephalus (8). The surgical morbidity and mortality rates of ETV were reported respectively as $0-20 \%$ and $0-1 \%$ in previously published serial studies (12). Many complications appear during the orientation of the endoscopic instrument. These are hypothalamic and thalamic injuries, injuries of he oculomotor nerve, basilar artery perforation, and intraventricular injuries. In addition, temporary CSF fistula, epilepsy, paresis of nerves 3 and 6 , meningitis, ventriculitis, cardiac arrest and arrhythmia are also potential complications $(4,6,9,12,13)$. Another complication is subdural hematoma. SDH is a well known complication of shunt surgeries occurring as a result of high drainage under negative pressure $(2,7,8,13,14)$. The incidence rate of this complication in patients who have undergone shunt surgery has been reported to be $10 \%$ in pediatric series and $30 \%$ in adults; however, this complication is very rarely seen after ETV $(8,9)$.

Some hypotheses have been suggested even though the physiopathology of subdural collection has not been clearly explained $(7,8,14)$. Beni Adani et al (1) accused per-acute intracranial variations occurring in the CSF (Cerebrospinal Fluid) regulation system in a short time. Schroeder et al (13) have suggested that large cortical punctures in patients with large ventricles may lead to accumulation of CSF in the subdural space causing subdural hematoma first via subdural hygroma then venous bleeding. Pietela et al, reported new variations in the CSF tract after ETV. Although CSF passage from ventricles to the subarachnoid system decreases the volume of the lateral and third ventricles, it does not lead to an increase in CSF absorption proportionally and consequently CSF may lead to subdural hygroma. Mohanty A et al (11) have suggested that ventricles collapse with the sudden reduction of CSF pressure and the occurrence of bleeding in the cortical veins may lead to subdural collection between the dura and the brain during CSF drainage, as observed in massive hydrocephalus after the refined brain shunt application similar to the ETV procedure. Kurschel $S$ et al (9) reported that covering the endoscopic space with fibrin glue after the completion of ETV and using hemostatic agents decreased subdural collection. They observed subdural collection only in one subject in a series of 20 subjects. However, the number of subjects was not adequate for a rarely seen complication in that study. Numerous hypotheses have been suggested on the occurrence of subdural collection.

We should ask the following question: Why does subdural collection develop in some cases but not in others? Although bleeding does not occur intraoperatively, we support the hypothesis that slow leakage into the subdural space with CSF pulsations and injuries occurring in the bridge veins after a long period of time lead to subdural hematoma. However, the occurrence of subdural hematoma cannot be connected to only one cause and it is a dynamic process. In our opinion, the initial opening pressure of CSF, administration of irrigation solution or the severity of the current, meticulous bleeding control and prevention of CSF leakage using glue are the important points which a neuro-surgeon should be careful about during the surgery.

Furthermore, congenital CSF absorption deficiency in adult patients, like pediatric groups, may play a role in the development of this complication. Pediatric group, adult group and subjects who have undergone a previous shunt surgery should be assessed separately. 
At present, ETV in obstructive hydrocephalus is a safe, reliable and efficient surgical choice for neurosurgeons with low rates of mortality and morbidity. However, rare complications such as subdural hematoma, hygroma and effusion should be kept in mind. Patients require follow-up BT and MR imaging in the postoperative period after ETV. Pressure-controlled catheters can be used during surgery to prevent excessive CSF drainage.

\section{REFERENCES}

1. Beni-Adani L, Siomin V, Segev $Y$, Beni S, Constantini S: Increasing chronic subdural hematoma after endoscopic III ventriculostomy. Childs Nerv Syst 16(7):402-405, 2000

2. Civelek E, Cansever T, Karasu A, Sabanci A, Sencer A,Kiris T: Chronic subdural hematoma after endoscopic third ventriculostomy: Case report. Turk Neurosurg 17(4):289-293, 2007

3. Dusick JR, McArthur DL, Bergsneider M: Success and complication rates of endoscopic third ventriculostomy for adult hydrocephalus: A series of 108 patients. Surg Neurol 69(1):5-15, 2008

4. Ersahin Y, Arslan D: Complications of endoscopic third ventriculostomy. Childs Nerv Syst 24(8):943-948, 2008

5. Freudenstein D, Wagner A, Ernemann U, Duffner F: Subdural hygroma as a complication of endoscopic neurosurgery: Two case reports. Neurol Med Chir (Tokyo) 42(12):554-559, 2002

6. Hader WJ, Walker RL, Myles ST, Hamilton M: Complications of endoscopic third ventriculostomy in previously shunted patients. Neurosurgery 63(1 Suppl 1):ONS168-174; discussion ONS174-165, 2008

7. Kamel MH, Murphy M, Aquilina K, Marks C: Subdural haemorrhage following endoscopic third ventriculostomy. A rare complication. Acta Neurochir (Wien) 148(5):591-593, 2006
8. Kim BS, Jallo GI, Kothbauer K, Abbott IR: Chronic subdural hematoma as a complication of endoscopic third ventriculostomy. Surg Neurol 62(1):64-68; discussion 68, 2004

9. Kurschel S, Ono S, Oi S: Risk reduction of subdural collections following endoscopic third ventriculostomy. Childs Nerv Syst 23(5):521-526, 2007

10. Maeda $\mathrm{Y}$, Inamura $\mathrm{T}$, Morioka T, Muratani $\mathrm{H}$, Fukui $\mathrm{M}$ : Hemorrhagic subdural effusion complicating an endoscopic III ventriculostomy. Childs Nerv Syst 16(5):312-314, 2000

11. Mohanty A, Anandh B, Reddy MS, Sastry KV: Contralateral massive acute subdural collection after endoscopic third ventriculostomy: A case report. Minim Invasive Neurosurg 40(2):59-61, 1997

12. Navarro R, Gil-Parra R, Reitman AJ, Olavarria G, Grant JA,Tomita T: Endoscopic third ventriculostomy in children: Early and late complications and their avoidance. Childs Nerv Syst 22(5):506-513, 2006

13. Schroeder HW, Niendorf WR, Gaab MR: Complications of endoscopic third ventriculostomy. J Neurosurg 96(6): 1032-1040, 2002

14. Sgaramella E, Castelli G, Sotgiu S: Chronic subdural collection after endoscopic third ventriculostomy. Acta Neurochir (Wien) 146(5):529-530, 2004

15. Sgaramella E, Sotgiu S, Crotti FM: Overdrainage after endoscopic third ventriculostomy: An unusual case of chronic subdural hematoma: Case report and review of the literature. Minim Invasive Neurosurg 46(6):354-356, 2003 